認定医ケースプレゼンテーション抄録

\title{
自家歯牙移植により歯冠補緅処置を行った症例
}

井野 智

\section{The Crown and Bridge Prosthetic Case with Autotransplantation of Teeth}

\author{
Ino Satoshi
}

\section{I. 症例の概要}

患者：34 歳, 女性.

主訴：入れ歯を作ってほしい.

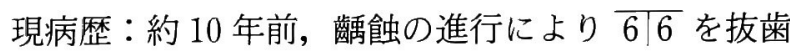
し, 左側に (5) 677 ブリッジを装着したが, 右側は放 置していたため, 7 が 6 相当部へ近心傾斜移動して きた. 3 週間前, 5 の歯根破折により抜歯となり, $\overline{6} \mid 56$ 欠損となった。

現症：欠損部顎堤は高度な骨吸収が認められず，口 腔清掃状態はやや不良で, 全顎にわたり生理的咬耗と 軽度の辺縁性歯周組織炎が認められた（図 1)。

\section{II. 診断と治療方針}

診断: $\overline{6 \mid 56}$ 欠損.

治療方針：欠損部は人工歯や義歯床を設計するため の垂直的スペースを確保できず，可撤式局部床義歯は 困難であった。 また, 支台歯の歯冠高径の不足から十 分な維持・固定が期待できないことや, 連結部の厚み の不足からブリッジの設計も困難であった. 研究用模 型や X 線診査の結果から, 上顎両側智歯は健全歯で ありながら対合歯がなく咬合機能に関与していないこ とや, 解剖学的に彎曲の少ない円錐型の単根歯である ことから，移植歯として有効であると判断した。ま た, 欠損部歯槽堤は移植歯の歯根径に対し十分な骨幅 と付着歯肉が認められた。

そこで，欠損部へ上顎智歯を自家移植することで支

神奈川歯科大学歯科補綴学講座

Department of Prosthodontics, Kanagawa Dental College

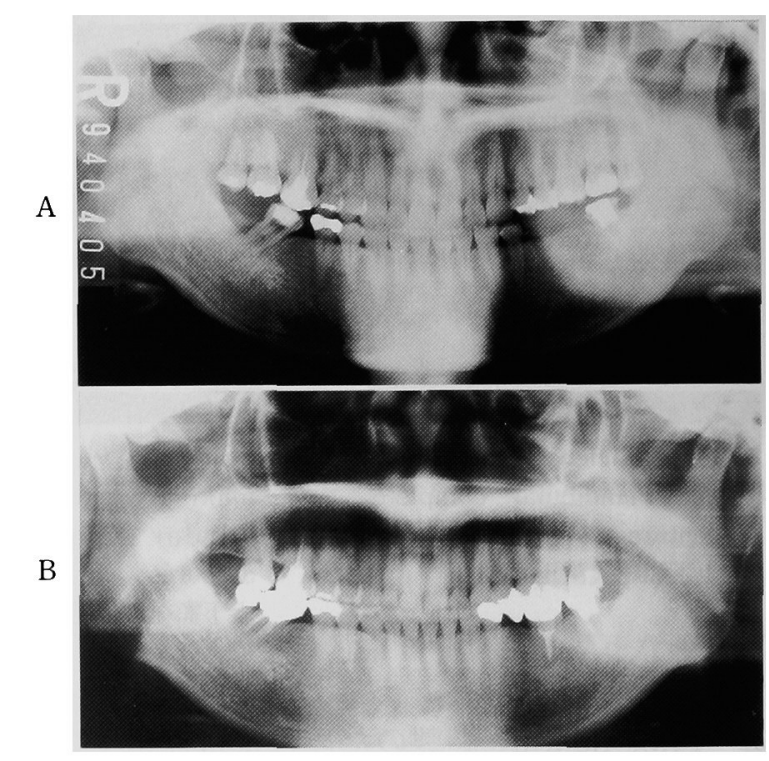

図 1 Orthopantomographies

A : before treatment, B : after treatment パノラマ X 線写真

$\mathrm{A}$ ：治療前, $\mathrm{B} ：$ 治療後

台歯数を増やし, 補綴装置のための維持・抵抗力を増 加させた後, 歯冠補綴処置を行うこととした.

\section{III. 治療内容}

移植前処置：(4)56(7) 暫間ブリッジによる咬合機 能の回復と歯周初期治療を行った.

移植は片側ずつ行い, 欠損歯数の少ない右側から先 に行った。

右側の移植：8」を7部へ移植し（1994 年 7 月）, 暫間固定を行った. 術後 3 力月経過時において 8 は, 移植床には生着したものの歯冠高径が不十分であり, さらに歯周ポケットが最深部で $4 \mathrm{~mm}$ あった。そこ 


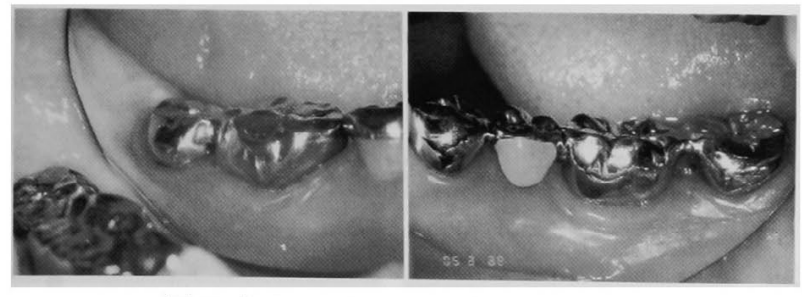

図 2 Intraoral views after treatment 治療後の口腔内写真

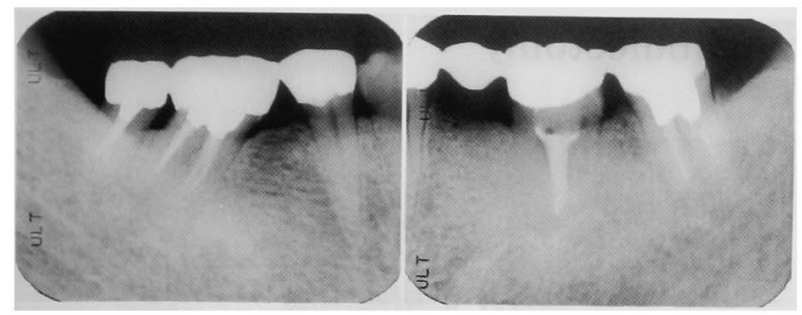

図 3 Radiographies of 4 years and 6 months later 4 年 6 力月後の $\mathrm{X}$ 線写真

で，補経前処置として歯周外科処置（根尖側移動術） を行った後, 76 連結冠による補緅処置を行った (1995 年 3 月).

左側の移植 : 8 を 6 部へ移植し (1995 年 9 月), 暫間固定を行った. 6 カ月後, (4) 5(6) (7) ブリッジを 装着した（図 2).

\section{IV. 経過観察と考察}

76 連結冠を装着した後, 約 2 年経過時（1997 年 2 月), $\overline{6}$ 近心煩側辺縁歯肉に発赤腫脹が認められ，歯 周ポケットが約 $4 \mathrm{~mm}$ に深化していた。この原因とし て, 近心傾斜・移動していた77を矯正移動させるこ となく可として補綴処置してしまったため, 5/との 歯間鼓形空隙が適正でなく，清掃性が困難な補綴装置 であったことが考えられた．幸い，歯周初期治療と歯 間ブラシの使用などによるロ腔清掃指導の徹底を行っ た結果, 腫脹の消退・歯周ポケットの改善 $(2.5 \mathrm{~mm})$ を得た。

左側の移植は, 術後初期から強固な付着歯肉を獲得 でき，歯周外科処置を必要としなかった. (4) 5 (6) (7) ブリッジ装着後も病的な歯周ポケットや動摇は生じて いない.これは, 術前の欠損部に十分な付着歯肉が存

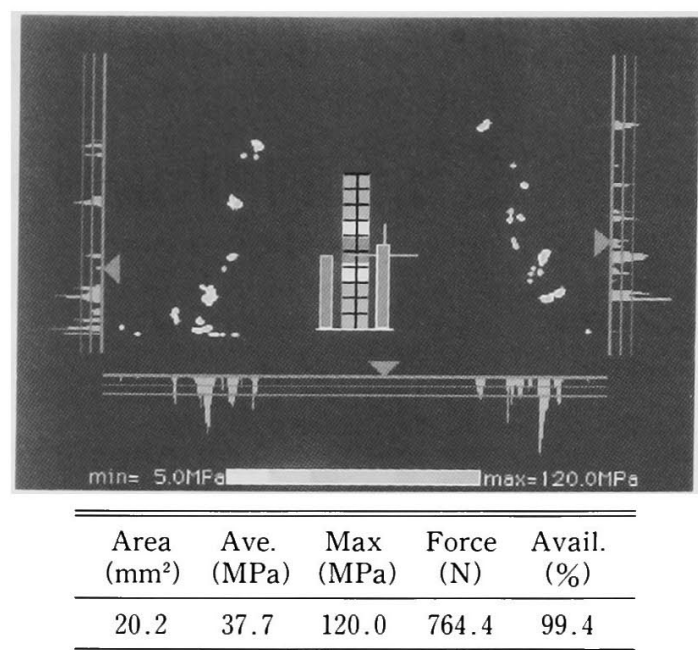

図 4 Occlusal contact balance after treatment 治療後の咬合接触バランス

在し，移植床として右側に比べ有利な条件であったた めと思われた。

最終補経装置を装着した後, 約 1 年ごとに経過観察 を続けており, 現在, 約 4 年半を経過した. 検診で は, X 線写真や歯周組織検査に加え残存歯の動摇度 測定（デンタル・モビリティー・チェッカー，共栄電 気）と, 咬合力測定（デンタルプレスケール, 富士 フィルム）による咬合接触バランスの評価を行ってお り，特記すべき異常所見は認められない（図 3，4）.

移植歯の予後不良症例は, 術後初期に生じる細菌感 染や，咬合のコントロール不足から術後後期に慢性的 に発生・進行する歯根の置換性吸収などがある ${ }^{11}$. 本 症例における移植歯は, 現在のところ異常所見は認め られないが，隣接歯と連結固定したことやブリッジの 支台歯として利用しているため, 通常のクラウンに比 べて清掃性や力学的条件が必ずしも恵まれた環境では ない. したがって, 今後発生しうる予後不良を回避す るため, 患者自身のプラークコントロールだけでな く, 長期的な咬合調整や歯周専門医との連携した包括 的チーム医療の実行が重要であると考えられる。

\section{文献}

1）下地 勲. カラーアトラス 入門・自家歯牙移植一理論と臨 床一 18-48, 京都：永末書店, 1995. 